\title{
重商制成功者の上流社会に対抗するが参入も図る自由貿易論者の パラディオ風/ロココ風ゴシック \\ PALLADIAN/ROCOCO GOTHICK OF FREE TRADERS AGAINST AND FOR FASHIONABLE MERCANTILISTS
}

\author{
岡田和正*, 田辺健雄**, 鈴木- $* * * *$ \\ Kazumasa OKADA, Takeo TANABE and Hajime SUZUKI
}

\begin{abstract}
Mercantilists formed a close league with free traders by sucking them up to new "Gentleman" class, and ruled England in the interests of the commerce and the Empire. Transformation of the architectural taste was continuously and finely graded as the English social order was. Snobs of free traders, who were looking for an adventurous advance into new worlds, inherited the idea of Palladianism and shared so called "Gentleman Culture". They mix the Palladian and the Gothick taste to make Palladian Gothick.

Rococo was agreeable for free traders who had strong bent for going to the expense of acquiring "surveyable wealth". Decorated Gothic reminds snobs of a pleasant success story, namely promotion to be "Gentleman" class, of Middle Ages merchants. They mixed the freedom and universality of Rococo, and Englishness of Decorated Gothic to make Rococo Gothick. Then, Palladian / Rococo Gothick became a status symbol for newly born gentlemen of free traders.
\end{abstract}

Keywords : Free Traders, Mercantilists, Palladian Gothick, Rococo Gothick, Snobisme 自由貿易論者, 重商制成功者, バラディオ風ジシッタ, ロココ風ジシック，上流気取り

\section{1.はじめに}

18 世紀英国ت゙シック (Gothick) 建築の中に, パラディオ主義 の反ロココ的, 合理的道德的風潮の受容を主題としてゴシックの構 成要素を古典的な規則に徉って意匠的に構成したパラデイオ風ニ゙シ ック (Palladian Gothick) ${ }^{1}$, およびフランス・ロココの自由奔 放な気質・精神と国際性を主題として英国伝統のゴシックを意匠的 に構成したロココ風ゴシック（Rococo Gothick）2) と呼ばれる様 相がある.それらの流行を三つの時代に分けて考察しよう.ひとつ は 1733 年頃から 1753 年頃にか什ての前期, もう一つはS・ミラ 一や・ウォルポール等アマチュア建筑家が活躍した ${ }^{31} 1753$ 年頃 から 60 年代までの中期, 最後はR・アダム等の手になる “Castle Style”のカントリー・ハウスが登場する 1760 年代4) 以降の後期 である. 本稿では，紙面の都合で，前期のそれを取り上げる.

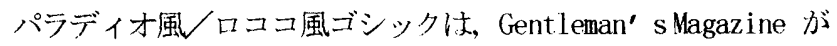
出版される（1731）など, 好古趣味が教養あるジェントルマンの素 養の一部である上認められつつあた頃，ウイリアム・ケント等が 中世に始まったゴシックの伝統を漠然と認識しつつ空想力によって 生多出し発展させたものであるう. それは, 後にバッティ・ラング レ一等により分類・体系化されて ${ }^{6}$, kent-Langley 期のت゙シックレ に、ても分類されている゙. それらの様相は，ホイッグ系ジェントル
マン社会における，本来の身分や地位上り「ちよっ上上流」の奢侈 的な生活様式を真似る消費競争Ｚ云の激しさは，英国人の上流 気取りあるい恔スノビム(snobisme) ${ }^{81}$ と外国人からかわれた —.-を棱ぎ，その時代に新たに「ジェントルマン」階䄲に吸収さ れていらたシティの商人や金融資本家および彼らに同調した専門職 (profession) 等社会の中核となっていた人たち（以下自由貿易論 者という）に愛好されたここでは，ジェントルマン八の階級上昇 願望の成就を巡る，自由貿易論者の，重融制成功者に対卞万接近・ 同化と対抗といら経済社会史の分析によって，それらの流行の原因 を解明し，意味付けをする。

それらの様相は, 自由貿易論者が「ジェントルマン」への階級上 昇願望を成就した象徽として, 卢ィラや住宅あるいは神殿などの庭 園建築物に用いられた傾向が強い。と同時に，18 世紀英国ゴシッ クは，国民を植民地獲得戦争八と駆り立てる心゙く愛国的感情を帠揚 させるたぬの象徵としての要素, 崇高・廃嘘趣味等の要素も混在し ている.そのため，乙れは総合的に解明されれる゙なららいが,ここで は, 新しい「ジェントルマン」たらのステイタス・シンボルと見做 されていた要素についての办去と，他仿別の論文で検討する。

尚,引用文中の二重括弧《》は, 読者がその前後関係を理解 できるようにした筆者の補筆である。

\footnotetext{
* 武蔵工業大学工学部建築学科 非常勤講師

** 武藏工業大学:工学部建築学科 助教授

*** 武藏工業大学:工学部建築学科 教授
}

Part-time Lecturer, Dept. of Architecture, Faculty of Engineering, Musashi Institute of Technology

Assoc. Prof., Dept. of Architecture, Faculty of Engineering, Musashi Institute of Technology

Prof., Dept. of Architecture, Faculty of Engineering, Musashi Institute of Technology, Dr. Eng. 


\section{2. 重商制成功者と自由貿易論者の協調と対抗}

18 世紀はじめ, 英国は重商主義的経済システム（以下重商制と いう）を成功させる．と，同時にそれは停滞を始める．その重商制 に生活の基盤を拀いていたのが，伝統的な大地主て既に政治的・経 済的・社会的に压倒的な支配階級となっていたホイッグ系の大地 主・大商人たち，即ち「ジェントルマン」階級の人たち（以下重商 制成功者という) である。彼らは，富と権力を同し階級・党派の仲 間の間に集中させてホイッグ党を組織し，土地以外の利害を奉ずる 人々，例えげ「ジェントルマン」としての生活様式を維持し，その 価值観を引き継いでいたシティの金融資本家，帝国各地に展開した 軍人・官僚などの専門職，対外的にすこぶる積極的・野心的な活動 を要求する立場にあった商人等自由貿易論者の上流指向者（snob） に対しても，「ジェントルマン」への階級上昇の門戸を広く開けてお く等腐心して協調を図り，主として重商制商業と帝国の利益にそっ て英国を真頭支配していた。

重商制成功者の次・三男坊たちは，フランスなど大陸諸国の貴族 のそれらとは違って，地主という自分の生まれに固執し上うとはせ ず，官職，陸軍，法曹界，上業，商業等で一財産つくるために家を あとにした. その事実は、こうした土地以外の利益を奉じる人々上 ホイッグ党との協調を促すに有利な条件として働いたの。

与党ホイッグの首相サー・ロバート・ウォルポール(以下サー・ ロバートという)は，ステュアート王朝復活といら、意味の反革命に 対寸る恐怖加，内政に找ける噯和政策と，国外に対して平和之， 野心的な事業を抑制する政策を採る。しかし，その政治は，頼廃 ${ }^{101}$ を助長才る一方で, 自由貿易論者との経済的利害衝突等を若起する。 パラディオ主義が盛んであった 1733 年, 密貿易（自由貿易）を取 り楴まる心゙く主流派の开・・ロバートにより上程された国内消費税 法案を巡って議会が紛紏する.コバム子爵は, 組織的反対運動门加 わったために，サ一・ロバートにより官職を迫放される，コバム子 爵は，サー・ロバート等の政治に異を唱えていた第三代バーリント ン伯等, パラディオ主義陣営の大勢のホイッグ不平地主・貴族たち 之共に，自由貿易論者に同調して党内の反対派一鞍替する。バーリ ントン伯等がパラディオ風建筑と自然主義の風景式庭園の美をもっ てホイッグ・ジェントルマンの理想を説く一方で，コバム子爵は， バーリントン伯の保護の下パラディオ主義陣営の建築家・造園家で あるウィリアム・ケントと共に庭園建築物の建設に着手し，パラデ イオ主義の受容と自由貿易論者の支持を視覚的に表現寸る. 同年, サー・・ロバートの政府の財務官でありながら，反対派の頭目的存在 でもあり自由貿易論者でもあったH・パラム虫，パラディオ風 ココ風ブシック様式を始める.

重商制成功者仙イッグの主流派と反対派の二派に分かれて政権 を争う. 自由貿易論者は, 重商制には反対だが，前者のサ一・バ 一ト内閣を打倒す心゙後者と手を組む. そして，ジェントルマン八 の)階級上昇願望の成就を狙う。

\section{3. ジェントルマンへの階級上臿願望の成就}

英国社会は、ジェントルマンの第 1 階層たる爵位をもつ貴族, ジェ ントルマンの第2 階層のジェントリ(地主)，中産痛としての市民等， そして第 4 階層の貧民大衆の 4 つの階層から成る ${ }^{11}$. 第 1 上第2
階層が，「ジェントルマン」と呼ばれる事実上同一の社会層に属し ている.ジェントリは，身分的には平民であるが，貴族とふつうに通 婚し，食卓を共にするなど，いすゆるジェントルマン文化を共有して いた. 更に, 支配階級としてのこのジェントルマン層が, 第 3 の中産 層に対しても開かれてていたことは先述したと抢りである.そして,4 つの階層の内部には数十にものぼる階層がなだらか炕連続して積み 重少孔ていた

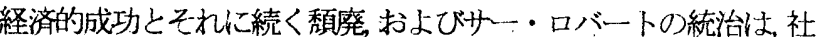
会的な序列（social order）に関わる諸問題にも大きな変化をもた らす。ホホイッグ系大地主（当時はその二代目ないし三代目が継いで いた)仙，重商制で成した富をもって，農業経営規模の小なるがた めの採算悪化の故に隣人たちが壳り出していた土地を買い集めて大

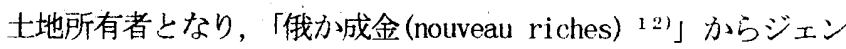
トルマン八の階級上昇願望を既に名実共に成就させていた。

一方，中央政府と結びいていた重商制成功者の次・三男たちも， 農業以外の職業によって一財産成し，主に邸宅用に土地を新規に購 入し ${ }^{13)}$, 地主 (ジェントルマン) 層八参入していった. 上流階級 之下層階級の中間の，いわ妕る中産階級劸力を増し社会の中核 となっていった。次・三男たちが一財産成した理由は多様だが，英 仏間の激烈な世界商業戦争にお沙る英国の勝利により，ある種の俄 か成金一一戦費調達のために発行された国債を保有しその利息で 収人を図る人々，軍の御用商人，軍人出身の地主・贵族などとなった人も多かった ${ }^{141}$.

以上の変化に伴い，社会的な地位を決定する要素は「経済力」の 大小加教義度の同一と所属員の世界観的連帯性という二点に絞ら れた ${ }^{15)}$ ．消費に関する身分的な制約は殆どなくなっていたので， 逆に, 人がどんな生活をしているかが問題となる. ジェントルマン 上認められるための資格・条件は，もち万ん血統の良さ，「家柄」 も重要視されていた。 が，そうした「生まれ良きジェントルマン」 に代わって，第3の階級から階級上昇に成功した倩ち良きジェン トルマン」が大幅に勢力を伸長しつめった．富者の「奢侈的な消 費」が新たなる需要を呼び，それが社会発展の原動力になると論じ られ，ジェントルマンの行なら経済的な美徳として正当化されてい た. そのため，大地主たちは，所有者の人格と社会的な身分を最も 明確にか心強力に象街与るといら意味での目に触れる富, 即ち「見 渡し可能（surveyable）な富 ${ }^{16)}$ 」八莫大な支出を欠くうけには いかなかった ${ }^{71}$.中・小地主たちも，大地主でなければ維持でき るはずのないほどの贅沢な生活様式を既に身に付けていた ${ }^{18}$. 生 活様式の上昇に配慮せざるをえない状況は，中・小地主たちにもお 上んでいた ${ }^{199}$ ．貴族たちが宮廷を理想とし，地主たちは貴族たち を理想とした如く，新参地主たちはジェントルマンへの接近・同化 を至上の理想として仰いだの。そそんなことから，ジェントルマン の概念は，一定の生活水準といら点においてもあやふやとなった。 「育ちの良さ」は親の経済力でもあるので，教養や広い意味での教 育に表れる経済力も，地位を決定するようにもなる。

教養・教育や生活様式の点で国際人と呼以゙礼るに相応しいことを 誇示守心゙く，美術の分野においてまたジェントルマンの立ち振る舞 い记おいて如何なる規則（rule）を造り上活る心゙きか，議論された。 それをリードしたのが，重商制成功者の哲人第三代シャフツバリー伯である。彼怯芸術に道德的亣明を加え，美上善は同一であると説 
く.続いてポウプは，金の正しい使い方を説き，富の価值は「自然」 上結ひ付いた徳」によって決定されるぶきだ21)と主張する．古 典的な芸術に関する知識は教養人の素養であり，その基礎がしつか りしていることが，英国ジェントルマンたる者の教養の一部である ベきだ22)と考えられた. また，テイストを解する人(Persons of Taste) あるいはジェントルマン (Gentleman of Taste) と認められ ることは，上流社会においてその人を有利なあるい懮越した立場 におくものであった ${ }^{23 !}$.

バーリントン伯たちは，グランド・ツアーに出か外てはラテン民 族に対して劣等感を抱き，受计継いできた文化の英国性を無視しあ い㤯少計価し，英国の採る心゙き文化の国際性を重視した ${ }^{24)}$. 彼 らは，規笧性と普遍的な妥当性を目指して伝統的に愛好してきた古 典主義的な世界観に内面的な感動を覚え，同じ感動に駆られた小さ なグループ，すなるち重商制成功者による上流階級を形成する．そ して，成した富の一部をヴィラやカントリー・ハウス等の建築一と 振り向ける. バーリントン伯等パラディアン陣営は，バロック建筑 がステュアート王朝復活という意味の反革命㧍よびカトリック復活 Łいう意味の反宗教改革を連想させるというので，ヴェネツィア商 業貴族たちの愛好したパラディオ設計の古典的な建策様式を選択卞 ることをもって教養度の同一を図ると共に，知力・財力（教養・生 活様式 の実力を示す，彼らは，それによって彼の世界の誰上りも 自分が寸ぐれてジェントルマン的であることを知り，仲間の他の上 流指向者たちから暗黙の諗証を得て，自分がジェントルマンである ことを確信するのである.こうして，パラディアン・テイストは， 彼らのステイタス・シンボルとなっていた.

一方，自由貿易論者たちは，重商制成功者や重商主義国スペイ に対抗して，新しい世界への冒険的な進出の機会を伺っていた。彼

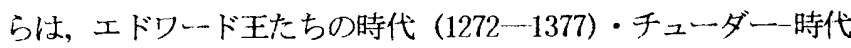
（1485-1603）に国籍が認識されて以来，英国の庶民を特徵づけて きた個別主義的な気質 ${ }^{25)}$, 即ち列強と戦うため心愛国的感情を沸 き上がらせる. ジェントルマン八の階級上昇願望をも強く抱いてい た彼らは，パラディアン陣営が揭げていた反ロココ的，合理的道徳

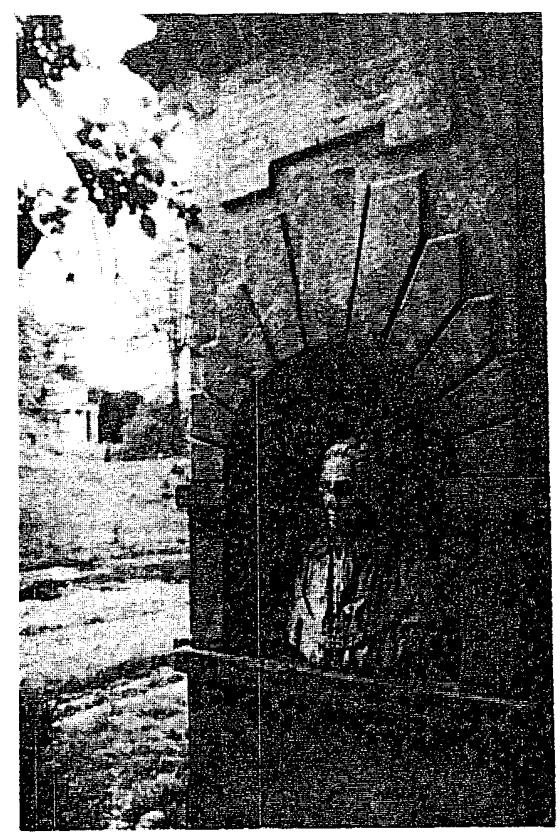

図一1英国の偉人たちの神殿

ウィリアム・ケント $1733-35$
的風潮を受容する一方で，貿易の自由や英国の独自性ないし個別性 を目指した，古代ギリシア・ローマ主義とは異なる barbarous な いしゴシック (Gothick) 主義的な世界観に内面的な感動を覚え, 同じ感動に駆られたグルーナ゙を構成する. そして, 英国に向から好 古的関心を強める等, 文化の英国性を重んじることをもって教養度 を同一とする. 営んでいた事業に成功して経済力を身に付けていた 商人や政府官職，軍人等の専門職（profession）の人たちは，自分 たちより一段上の社会的身分にある古くからのジェントルマンの思 考・行動様式に追従し準えることにより，「われわれもジェントル マンである」と自らが所属する同じ世界の有力者たちに対して主張 し26)，仲間の暗黙の同意を得る. そこでは，パラディオ主義とゴ シックおよびロココとゴシックをそれぞれ絢い交ぜて出来たパラデ イオ風、ロココ風のゴシック・テイストが，この時代に新たにジェ ントルマンへの階級上昇願望を成就させていった自由貿易論者たち のステイタス・シンボルとなった.

以上，重部制成功者と自由貿易論者につい見てきた英国特有の 上流指向の心理状態は，称替と揶揄ないし少々の軽茂も含めて， 「粋な見栄 (snobbery) あるいは上流気取り」と言われているが， この心理状態力英国近世の経済的繁栄の原動力の一つをもなったこ とは否定できないであろう. その行為は美化され，正当化されて， $\mathrm{R} \cdot \mathrm{H} \cdot$ トーニ一も言う如く, 富というものの従来の社会的な悪徳 の経済的美徳への，ひいては道德的美德入の転化 271 となっている.

4. 自由貿易論者による, 反ロココ的, 合理的道德的風潮の受容 ストり園の庭園建築物——コバム子爵

1733 年, 政治活動を断念したコバム子爵は，ストウ園の改良に 着手寸る ${ }^{28)}$. 「英国の偉人たちの神殿, the Temple of the British Worthies, 1733--35」（図-1），「古代の道德の神殿, the Temple of Ancient Virtue，1733-35」および「現代の道徳の神殿, the Temple of Modem Virtue, c.1737」(図-2) が建設される.設計者は，と もにウィリアム・ケントである. コバム子爵は，以前にパラディオ 主義陣営の総帥であるバーリントン伯からその被保護者であるケン トを紹介されていたが，この年に彼を招聘している．それらの神殿 は，建築主の社会的イデオロギーを図像的に宣明寸るという機能を 備えており 29), パラディオ風ゴシックによる庭園建築物の発展・ 展開に影響を与えたことで極めて重要な役割を果たしているので, ここで取りあげる.

「英国の偉人たちの神殿」には，16人の偉人 ${ }^{301}$ の胸像が祀られ ている，うち8人は，“大改革”主義を象微するGibbs Building ${ }^{31}$ に祀られた後にこの神殿に移された. 残り(註 30 のの斜体文字)が， この神扸の新築に際して新たに加えられたもので,イコンとして重 要であるので, クラークとハッセイの説明を次に紹介寸る. 新参の 1 人がパラディオ主義の父イニゴ・ジョーンズである. サー・ロバー トの政治に異を唱える反対派のバーリントン伯は，ホイッグの理想 を表すバく、イニゴが英国に紹介した建築様式を採用した。 それゆえ， 彼はその中に加えられた ${ }^{321}$.残りの 7 人は，反対派のイデオロギ 一の或る特定の一部分を主張している.例えば, グレシャム卿は， 「商人という名誉ある専門職 (profession)」およびシティ(首相サ 一・ロバー一トに反対卞る勢力）の利益を象徵寸る ${ }^{33)}$ 。ジョン・バ 


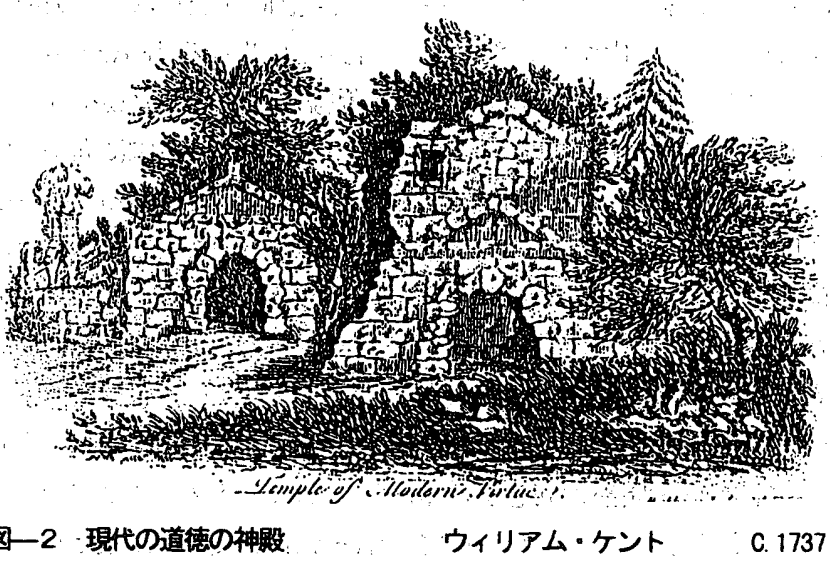

一ナードは，有害で不正な株式取引に断固として反対し，国債の利 子率を引き下げて国力を增大させるべく最大の努力をした ${ }^{34}$. そ してポウプは, 悪徳を懲らしめるべく辛辣な機知をもってし，人間 性の一たる徳を称揚す心゙く詩の雄并性をもつてした ${ }^{3.5 \%}$ ：ポウプは, バーリントン伯八富の効用につけて, 1731 およびコバム子爵人人間 の知識と性格について,1733，という書簡詩を送って道徳性を説き， 金満家サー・ロバート等がくだらないことに金を浪費していること を風刺し，バーリントン等上流階級に金の正しい使い方を教えた。

:古代の道德の神殿」:は，4人のギリシアの偉人を最も純粋な規 範たる古代の道德 ${ }^{36)}$ のイコンとして毙っている. 伝統的に統治の 理想とされていたものが，サー・ロバートの行政府の隋落と対比さ れている ${ }^{371}$. その神殿は，理想的人物の墓を意味している ${ }^{381}$. 即 ち; サー・口バート小行政府は死んでいると諷刺されている。「現代 の道徳の神䝿」はこれらの二つの神殿近くに配置されていて, 廃墟

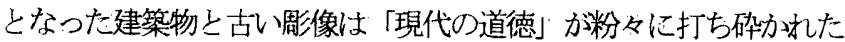
状態になっていることを人々に示さんと意図して作られている39). 首のない彫像がサ一・ロバートであることは明らかであるう。

それらら神殿の図像的テーマの題材上表現形式は次の通りである. 題材として取り上げられている内容の一つは，サー・ロバート等金 満家による, 贅沢な饗宴などくだらないこと八の富の浪費と，第三 代バーリントン伯等パラディオ主義を奉ずる反対派ホイッグの「ジ エントルマン」たちが理想とする道德的な生活様式，即ち社会的覀 徳としての富の, 自然と結びついたパラディオ主義建築や自然主義 風景式庭園等への転化と対比されていることである.もう一つは， サ一・ロバ-上内閣の；野心的な事業（自由貿易）に対する抑制政 策，およひ南海の泡沫事件に関わる不正な株式売買や国債の利子率 を不当に高く維持寸る等の放漫政策と，コバム子爵等の公正で自由 な商業取引促進の主張とが対比されている. そして，それらを表現 する形式として，古代の道徳のイコンたるギリシアの偉人たちの彫 像やイニゴ・ジョーンズや反刘派の利益の或る部分を主張寸る人々 の胸像, 更には廃墟となった神殿之首のない彫像等の庭園建築物が 用いられている.その底意は，富の正しい用法は，趣味の根本は良 識にあるからして，「自然」と結ひ付いた徳，即ち反口ココ的，合 理的道德的風潮を宣明するパラディオ主義建築や自然主義の風景式 庭園などの「見渡し可能な富」の美の受容にあり,またサ一・ロバ 一トの政府は反対派との協調を図って商業と帝国の利益にそって統 治する心゙きである，というものである. 以上からコバム子爵は, 反対 派二自由貿易論者に鞍替えしたけ扎ども, 同盟したバーリントン伯
一派の「ジェントルマン」としての生活様式たるパラディオ主義の 価值観を受容した新しい「ジェントルマン」階層を形成したいよ考 えていたことが分かる。

5. 反ロココ的，合理的道德的風潮と英国性・国際性の糊交ぜ. (1)エッシャーの家— 认ンリー・ペラム

a . パラディオ風ゴシック

ヘンリー-・ペラムは，後述するジェームズ・ドーマー，ウィリ アム・スタナップ等と同様に, ホイッグ系大地主の出自とは言えど 非長子 (次・三男) であったので，爵位や財産を相続できなかった. それゆえ，彼は，官職という尃門職の地位を金と縁故関係によって親 に買ってもらい大蔵官僚の地位にまでのぼりつめていた。彼は、ジ エントルマン階級への新規参入を果たす心゙く, 土地ブームにあった 1729 年, エッシャー・プレイスに土地を購入する. 彼は, サー・ロ バートの政策に強い反対をしていたが, ホイッグ党内の反対派(農業 以外の利害集団) との協調ないし祭密な同盟を重んじていたので, 反 対派の自由貿易論者の barbarous ないしゴシック主義的な世界観を 持っていながらも,ホイッグ系「ジェントルマン」としての生活様 式を維持し，その価值観を引き継いでいたのはもちろんである.

ペラムは、ゴシックによるヴィラの設計をウィリアム・ケントに 依賴寸る. それが, 敷地内に廃㠊となって残っている初期チューダ 一様式による赫棟瓦造のゲイトハウスを改装しその雨翼にウィング を増設して造った, パラディオ風レロココ風の様相を呈したジシッ クによるヴィラ，「エッシャーの家１729-39」(図-3) である. その意匠的な特徵として，他と区別寸るべくその頂部にアテックの ような屋根を設えられた二つ塔；あるいは他と違って見えるよう にその頂部にペディメント状のパラペット等を帽子のようにから゙せ た張り出し䓗およびポーチ等に，バーリントン伯が特別な感情を抱 いていた，意匠的構成要素の分推，即ちスタッカート式とも呼ばれ ている過度の分節化 ${ }^{40)}$ という建築手法を見て取ることができる. 更には，塔，翼，張り出し空，ポーチ，尖りア一千付きの開口部， 三つ葉飾りや四つ葉飾りを象った空等の建築意匠的要素が，パラデ イオやジョーンズが用いたあるいは推奖した古典的な建築の規則に したがって，それぞれに異なったヴォリュームを考慮して，左右対 称に正しく配置されていることも挙げられる.

英国のパラディオ主義 (Palladian) 建築は，18 世紀のはじめ， 英国経済が衰退し始めたと考えた重商制成功者たちによって創られ

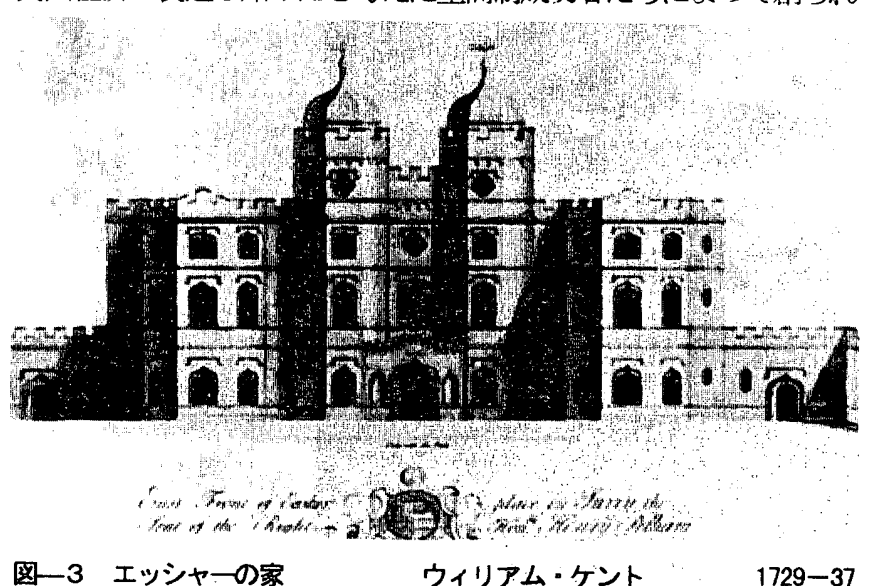


た簡素な様式であり，その建築の目的は，重商制貴族社会を，16 世 紀半ば以降のヴェネツィア共和国や帝政初期ローマのアウグストゥ ス時代のような，ホイッグが理想とする社会とし，それを安全に維 持存続させるためのシンボルとして役立たせるためであった. 大陸 のカトリック諸国で流行した豪華で人工的なフランス・ロココ41) の装飾に対して, カトリックの反宗教改革(the Catholic CounterReformation）および反名誉革命に恐孔を抱く英国では，フランス をはじめとするカトリック諸国と宗教的・政治的・経済的に対立し ていたこともあって，フランスによる世界制霸を想起させるバロッ ク芸術と,それに結びあうロココ芸術は敬遠され，自然の建築であ る421パラディオ風様式を好む傾向が強くなっていた．同じく普遍 的で惊あったが, 経済が上り坂にあった 17 世紀の終わりから 18 世 紀の初期にか心ての重商制成功者たちが愛好した英国バロック建築 や，同じく上り坂の経済にあった自由貿易論者たちの好んだロココ 建筑を, 経済が停滞状態にあったホイッグ系大地主の二代目ないし 三代目の人々が厭わしく思い採用しなかったのも無理からぬことで あったこのことは別稿にて詳細に検討しよう.

先述の第 3 の階層にあった自由貿易論者たちは，斯宅を建設する ための土地を購入してジェントリ (地主) 層への階級上昇を果たして 新たにジェントルマンの第2 の階層に吸収される栄誉を獲得せんと する.そして更に，彼らは，第1 の階層である伝統的な大地主で支 配階級となっていたホイッグ系「ジェントルマン」階級の人々の上 流社会八の仲間人りを目指して社会的な序列の階段を着々と昇る努 カをする.したがって, 自由貿易論者たちは，商圈の海外一の拡大， 即ら植民地獲得のための闘争心を昂揚させるための象徽としてゴシ ックを愛好寸る傍ら，連続的な変化として，第 1 の階層の重商制成 功者たちとジェントルマン文化を共有寸ることを重んじたので, 建 築もゴシックをバースにパラディオ主義を接ぎ木するこいう段階 的・連続的な変化を工夫したのである. 重商制成功者から自由貿易 論者の間の社会的な序列の連続的な変化，およびその事実に伴って 起こってくるパラディオ主義からゴシックまでの建築文化の連続的 な変化ぶ, パラディオ風ゴシックを産んだと言ってもよいであろう.

$$
\text { b. ロココ風ゴシック }
$$

「エッシャャ一の家」のもう一つ意匠的な特徴として，うねつた 曲線や渦巻き形状に対寸る好みが挙げられる．二つの塔の屋根に見 られる萑花曲線 (ogee)ア一チ，空まぐさを内弧と外弧が共に上部 に折れ曲がった苟花曲線による尖リアーチで飾った空，およびその 上部のチューダー様式の平べったい雨垂れ石が, ロココの装飾手法 によって姿・形状・性質を自由奔放に変化・融合され造形されて一 対となった開口部の装飾, 四つ葉飾りを象った空等に, 見て取れる.

18 世紀前半に活躍した哲学者デイヴィッド・ヒュームによる Association の概念を用いて，苟花曲線に見られるうねった曲線や 渦巻き形状に対する好みについて検討してみよう。

ペラムは，同じ自由貿易論を主張する仲間の人々に，ロココ風ゴ シックを用いて改装したヴィラの「エッシャ一の家」を見せる.そ れを見た人々に，かって 14 世紀において事業に成功した新興都市 商人たちの田舎における隠遁生活の成就の象徴となっていたマナ 一・八ウスを想起させる. 14 世紀新興都市商人たちが野心的・冒 険的な事業を成功させたと同様に，ペラム自身も財務官といら官職 を勝ち得て，“第三代シャフツベリー伯流”に実業の世界加らの隱
遁を気取って田舎における隠遁生活を始めることによって, 自分の 知力・財力 (教養・消費生活様式) の実力を示そうと図る. パラム は,「エッシャーの家」を見て中世のマナー・ハウスを想起した仲 間の人々をして, 自身が同じ自由貿易論者の誰よりもすぐれてジェ ントルマンであるという方向に連想を馳せさせんとする. そして， それを,同じ世界の他の上流志向者たちから暗黙に認証してもらう。 その結果, 彼汁自らがジェントルマン八の階級上昇願望を成就した ことを確信するのである. 教羑あるパラムは，この物語を語る心゙く ロココ風ゴシックによる「エッシャーの家」の建設を意図したと考 えられる。

苟花曲線に見られるうねつた曲線や渦巻き形状に対する好みは， 事実上英国の伝統に根ざしたもので，1300 年の様式，つまり装飾 式ゴシック (1290-1375) 様式から，18 世紀の画家ホガース, 詩 人銅版画家のブレイク，さらにそれ以後までの流れであると言われ ている ${ }^{43 !}$ 。装飾式ニ゙シック様式が流行したのは，エドワード諸王 の治世（1272-1377）であり，英国が末加工の羊毛の大量輸出から 始め，毛織物の輸出に転じ国際的な競争力を身につけた時代であつ た. 商工業が発達し, 中産商工階級も急激に台頭した. 成長を続け ていた重商主義的な英国経済の下，14 世紀半は頃に建築された装 飾式ゴシックによるマナー・ハウスの多く，例えばペンズハースト (Penshurst Place) は，しばしば，毛織物に関連した事業に成功 した新興都市商人たちの田含におうる隠遁生活の場となった ${ }^{44)}$. つまり，装飾式ゴシックを，ジェントリ（地主）層に参入した証と して，また新興都市商人の上流志向者（snob）たちのステイタス・ シンボルであったと見做したとしても，妥当であろう. その指摘は, ロココ風ゴシックが，それを見る人の胸中に 14 世紀英国の新興都 市商人たちの「ジェントルマン」への階級上昇という心弹を連想を 促すに格好な様式であったとする，おれわれの考えの妥当性ない儿 正当性を証明するためのよき資料となっている.

ペラムは，初期チューダー時代の赤棟瓦造のゲイトハウスを改造 して創った「エッシャーの家」を見た自由貿易論者に，チューダー 時の初期，貴族に反対して商業貿易を奨励寸る国王に心底味方した 中産商業市民層の多数が事業に成功して, 新たに貴族層八と参入し ていった事実を想起させる. そして，自由貿易論者をして，中産商 業市民層がかつてそうであったように，ペラム自身も同じ反対派の 噰よりも寸ぐれて「ジェントルマン」であるという方向一連想を馳 せさせる. その結果，自由貿易論者の上流志向者の暗黙の認証を得 たものと考えられる. パラムが設計者のケントに対し，敷地内に廃 墟となって残っている初期チューダ一時代の赫棟瓦造のゲイトハウ スの積極的な活用，およびて近隣のハンプトンコートにおいてケ ントが携わつていた「アン・ブリンのゲイトの再建計画, 1732 」 と同様な方針て意匠することを設計条件として要請している45) 事 実は，人の心中に機能する Association の働きによってゴシックが 「ジェントルマン」への階級上舁と常に結合している，といらわれ われの論を補強してくれる，なぜなら，棟瓦造は14 世紀に英国に 導人され，初期チューダー時代には赫棟瓦造が貴族層への階級上昇 に成功した商人たちのゴシックによる大期宅にも用いられていたこ とが知られていたので，廃墟となって残っていた赫煉瓦造のゲイト

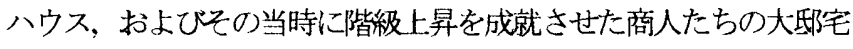
の様式を採用して造った赫䐈成造のハンプトン・コートは，ペラム 
等新参地主たちの胸に，そこに住んでいた人々の「ジェントルマン」 八の階級上昇の成就等, 生き生きとした快い回想の感動を呼び起こ すものであったからである.

ウィリアム・ケントは，造園家として活躍した一方で，建築家と して自然主義の風景式庭園に用いられていた原理を建築設計入も応 用寸る. 即ち, 英国の伝統である装飾式ゴシックと, 当時先進大陸

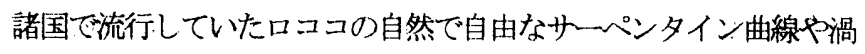
巻き型形状を䍃い交ぜにし，反古典的でしかも英国的特質上国際的 特質を併せ持ったロココ風ゴシック（Rococo Gothick）を創造す る.「《中世の》ゴシックに相当する脆弱で装飾的な形式を発展させ たのはケントであることは，疑う余地はない．・・ケシトのゴシ ックは 18 世紀の中葉ドーヴァー海峡の向こう側から，パラディオ 主義が盛んであった英国に時折旋風のごレき影響を与えたロココに

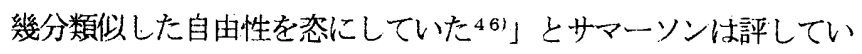
る.それは，ケントのゴシックが，中世のゴシックとロココを綯い 交せた新しい装飾的な形式であるという考えの妥当性を補強してく れるものである.

そこで注目す心゙きは, 自由貿易論者の建築主のペラムの設計要求 に答えたケントが，舶来品のフランス・ロココを取り入れゴシック と綯い交ぜる際に採った政治的・経済的・社会的ならざ建築的な 手法である.

ロココ様式 (genne rocaille) は, バロック未期のフランスで, バロックの線と動きを借り受けて，Zれにもう一捻りを加えること に上って創られた奢侈的な様式である。欧州大陸では 18 世紀のご く初期の頃から中葉にかけて，フランスの窝廷をはじめとする上流 社会の人々に愛好されていた最新式の高貴な趣味であり，また経済 が繁栄しバロック式の建築が盛んであったイタリア，南ドイツ，才 一ストリア，スペイン等のローマ・カトリック諸国で，それは流行 していた，ロココは英国人にとっては，反古典的でしかも，パラデ イオ主義と同様にあるいはそれ以上に国際性豊かであり，舶来文化 の香りも高く高級感を備えている. 高価な材料をふんだんに使用し， 金びかで豪華な，そして熟練度の高いクラフトマンの労苦が過剩で さえあるほどに込められていて, 装飾が複雑で込み入っているので, ロココは贅沢で高価であることを意味していた ${ }^{47)}$. それいえ，中 産層のシティの商人や金融資本家等一自由貿易を旗印にして, 対外的にすこぶる野心的・畕険的な活動を要求する立場にあり，こ の立場が 17 世紀末加ら 18 世紀初頭にか时て英国を国際的に活動さ せ，しかもその目的をある程度達していたー…の上流志向者が知 力と財力（教養と生活様式）を誇示寸心゙く，見栄やなぐさみあるい は見せびらかしから生まれてくる「奢侈的な消費」，更には「見渡 し可能な富」八の支出好きに叶う様式として, また競って富ないし 財力を誇示する道具立ての一つとして，更には，国際的だが，規範 性に縛られ，他のスタイルを綯い交ぜ新しい豊かな装飾様式を創造 寸る自由が許されない古典的なパラディオ主義を揶俩する様式とし て、ロココは誠に都合のよい様式であった.

ジョン・ロックは言う. 流行品はステイタス・シンボルであった がゆえに「価格が高いほうがよく売れる481」と．続けて「国産品」 が国民の愛好物になることはめつたにない49) と指摘する。「妥当 な価格て販売に供せられたわが国のいくつかの商品が軽荗されてき たのにその同じ物がフランス製として二倍の価格として売られる

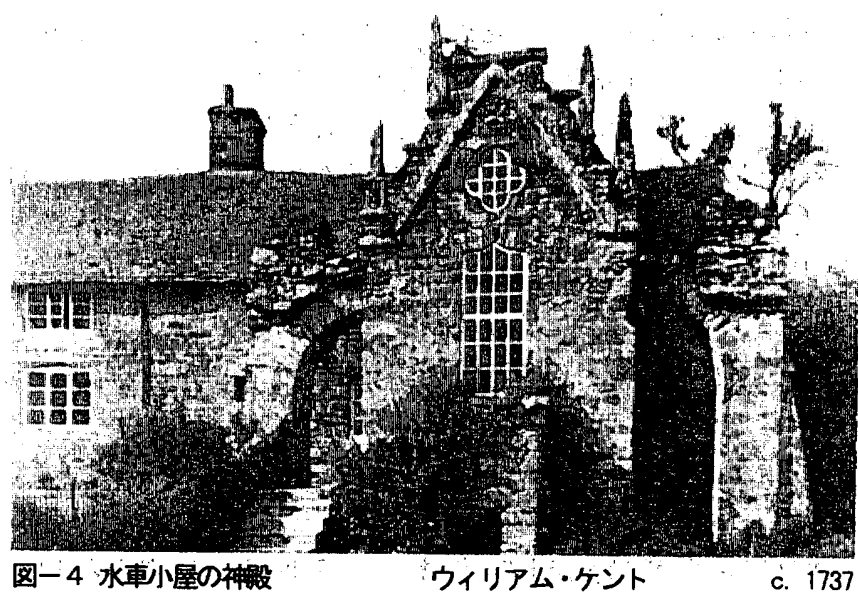

時には，競って求めら，見せびらかされる. 珍品や外国品を誇示し 得たとき; 人々は裕福な暮らしをしていると考えられたり，言われた りする.それでこそ; 輸人品は競って富を誇示する道具立てのううに なり得るのだ50」」と, ジェントルマン階級の人々あるいはそこへの 参入に努める人々心舶来品崇捙熱を指摘する.

自由貿易論者の上流指向者にとっても，ロココは,パラディオ主義 を採る重颜制成功者から受容していた反口ココ的, 合理的道德的な 風潮のゆえに,その反フランス意識とも相容れることのない好まし からざるテイストでもあった.

ロココの好ましからざるテイストとしての部分をそぎ落とし，ロ ロココの自由性・国際性・舶来品の高級観等のゆえに好ましい趣味 としての部分を強調して, 新しいロココのテイストを創り上げんと する試み㫑なされる. 即ち, 建築的には, 英国生まれの樹木, 即ち ゴシックといら代々受け継いできた英国性に，外国の若芽，つまり 舶来品のロココという国際性を接ぎ木しあるいは絢い交ぜ, 害い換 えるとロココの人工性を自然なものに置き換えるという手続きを採 ることによって, 自然な建築としてのロココ風ゴシック (Rococo

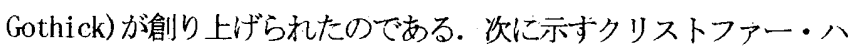
ッセイならびにホレス・ウォルポールの言葉は，われわれて考えが 妥当であることを裏付什且つ補強してくれるので, 紹介しよう. 即ち, ハッセイは、ロココ風ゴシックが形成されていったこのような動き を「ロココ精神の自然化ないし㷌化51」と呼ひ，「流行のフランス 式装飾として取り人れられたもの《ロココ》は,『自然の事ども

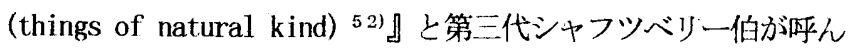
だものに対寸る, 沸き上がりつつあつた熱狂と融合するようになっ た.このロココの精神の自然化ないし帰化の過程は三種類あり，… 一㑑然の建築, 即ち『ゴシック(Gothick)』建筑の関心の高ま

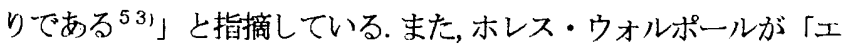
ッシャーの家」のロココ風ゴシックによる建築意压について，「そ こでは、ペラムの愛好を得るべくケントと自然が競い合ったそそこに

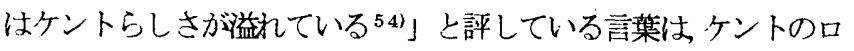
ココ風ゴシックが自然な建築であると考えられていたことをよく示 している.

(2) 水車小屋の神殿 ——ジェイムズ・ドーマー

ジェイムズ・ドーマーも非長男であったので, 家を後にして軍人 となっていた. 彼はバーリントン伯と親密な友人の一人である.

彼は兄の死によって，1737 年ラウシャムの所領を相続する. 彼 は,かってブリッジマンが設計した庭園の線を柔らかくするべく, 
ウィリアム・ケントに助言を求める ${ }^{55)}$. そして, 庭園の一部におい てゴシックを用いた美的改良が開始される.住宅の北北西の方向に ある「Temple of Echo」あるいはアポロの像の前から,ラウシャム の所領の境界を流れるチャーウェル川に沿って北の方角を望むと， バイスターからエンストンへ向から道路のその渡河地点に 13 世紀 末期に架けられたツフフード橋が見える.その橋の遥か右手, 川の 右岸に広がる農地に，ロココ風ゴシックによる「水車小屋の神殿, the Temple of the Mi11，1737」(図-4)が建築される. 設計は,これ もパラディアン陣営の建築家ケントである. 四つ葉飾り式空, 装飾的 に用いられた飛控え等の意匠的な特徴が挙げられる.特筆ず゙きは， サッシュ空の空まぐさの部分のアーチに見られる萑花曲線(ogee) あ るいは二重曲線の応用である.

(3) レイビー城のゴシックによる改筑——ー゙ーーーード卿

レイビー城は 12 世紀に建てられたジシックの城である.バーナ 一ド卿は， 1740 年代から 1788 年にか讨て城を修復し，一続きの 部屋をバラディオ風 の改修工事で,その猟園に隠遁所と湯殿(retreat and bath house) が建設され，両方のウィングにアーケードが施された「ゴシック (Gothick)のパヴィリオン」(図－5)が設計されている. 設計者は ダニエル・ギャレットと言われている ${ }^{56)}$. パラディオ主義の熱狂 者の一人である, カ一ライル卿の義理の息子であるサ一・トーマス・ ロビンソンがチズウィック・ヴィラのダブル・フライトの入り口階 段をモデルにして,キャッスル・ハワードの霊廟の台座部分を変更 しようとした際に，ギャレットは設計の実行委員として働いた. そ の作品はバーリントン派の人々，主にサー・トーマス・ロビンソン によって合意されている. それゆえギャレットは，ゴシックによる 庭園建築物の設計において，ケントの直接的な継承者であると言わ れている57.

(4) アイスローブ・ハウスのゲイトウェイー-ーハリントン伯

1733 年, ポーランド継承問題は欧州諸国を戦争に巻き込んだ. サ 一・ロバートはそれに関わらないよう平和政策を維持したが, ハリ ントン伯等ホイッグ党員は，彼の政策の分別に疑問を抱いた. 1739 年, 大ピットはスペインの領有する南米の植民地を奪い取るべく英 匡議会にて主戦論を展開する ${ }^{58)}$.サ一・ロバートの政権の中枢に いたニューカッスル公が戦争の必要性を確信守ると, 後にゴシック による模擬の城，「ウィンポールの城，1749」を建設する大法官の ハードウィックおよひ国務人臣のハリントン等は，それを支持し， 英国の開戦をサー・ロバートに迫って ${ }^{59)}$ 反対派に転じた.

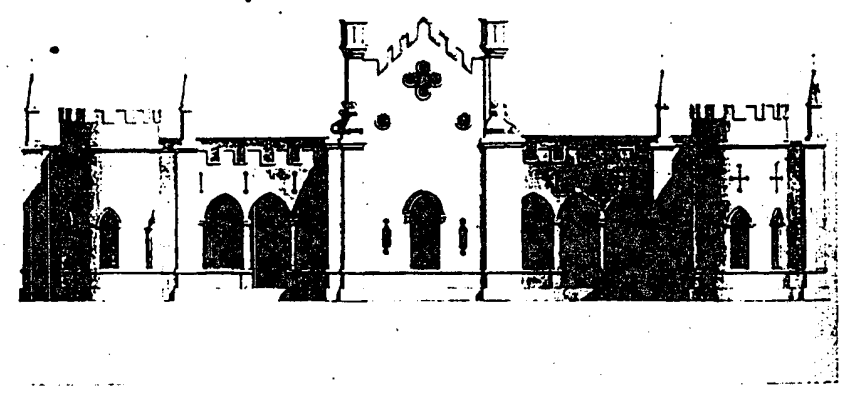

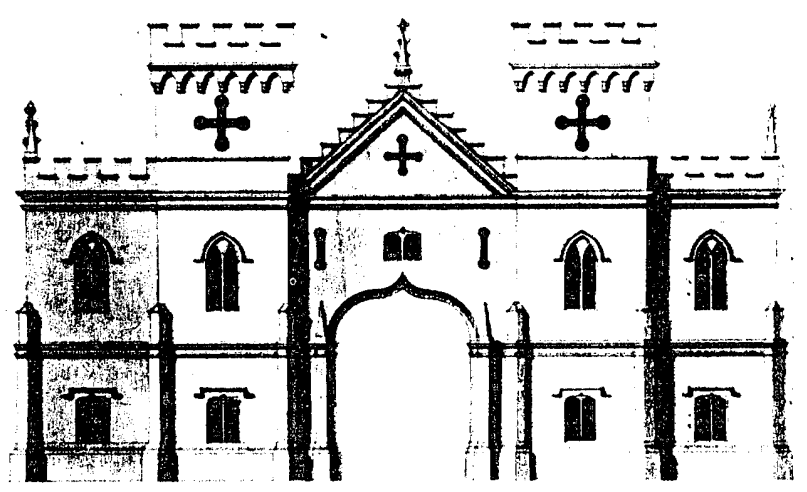

図ー6 アイスロープ・ハウスのゲイトウェイ アイザック・ウェア 1751 初代ハリントン伯, 即ちウィリアム・スタナップは, パラディオ 風 ロココ風ゴシックによる「アイスロープ・ハウスのゲイトウェ イ，1751」（図一6）在建設する.設計者はアイザック・ウェアであ り,サー・トーマス・ロビンソンの仲間, つまりパラディアン陣営 の一人である. その意匠的な特徵として，平面が四角形の塔とその 頂部に設えられた胸壁を備えたパラペット，あるい徤物中央の入 り口部分の頂部にあるペディメント状のパラペット等に, バーリン トン伯が特別な感情を抱いていた過度の分節化といら建築手法を見 て取ることができる.

\section{6. 結論}

重商制成功者は，18 世紀はじめから中葉にか计て，重商制秩序 の安全維持を図る心゙く，自由貿易論者の上流志向者を新たに「ジェ ントルマン」階級に吸収する等して彼らとの緊密な同盟を育て上げ， 商業と帝国の利益にそって英国を支配した. 各階層の社会的序列は， 連続的にいくつも積み重なった階段状になっていて, 上下の関係こ そあれ階級闘争の如き敵対関係は起きなかった. 建築の趣味の変化 も, バラディオ主義からゴシック好みまで, 支配形態と同様に連続的 であった 上流志向者は，新しい世界への野心的・冒険的進出に燃 えつつも、いわゆる「ジェントルマン」文化を共有することを至上 の理想として仰いだので，パラディオ主義の反ロココ的，合理的道 徳的風潮を受容し，パラディオ主義とゴシックを線い交ぜ, パラデ イオ風ゴシックを創った

最新式の高貴なテイストである二重曲線のフランス・ロココは, パラディオ主義を揶掩する様式であり，また事業を成功させ「ジェ ントルマン」階級一の参人を図らんとする自由貿易論者の「見渡し 可能 (surveyable) な富」への支出好きに叶う様式であった. 憼花 曲線の装飾式ゴシックは，かつて成功した新興都市商人たちの「ジ エントルマン」 八の階級上昇願望成就という心弾む連想を促寸恰好 な様式であった．上流志向者怡，知力・財力の実力を示す心゙く、口 ココの自由性・国際性と装飾式ゴシックの英国性を絢い交ぜ，新し いロココ風ゴシックを創った。

こうして, 1733 年頃から 1753 年頃にかけてパラディオ風 コ風ゴシックは，「ジェントルマン」への階級上昇願望成就の証と して, 自由貿易論者の上流志向者のステイタス・シンボルとなった。

图ー5 ゴシックのパヴィリオン ダニエル・ギャレット～c. 1752 
註 記

(1) Al istair Rowan, Cothick Restoration at Raby Castle, Architectural History, Vol. 15, 1972, p. 23 执よ゙ Michael McCarthy, The Origins of Gothic Revival, Yale University Press, 1987, p. 33 . $\quad$ (2) ibid.

(3) John Surganerson, Architecture in Britain 1530-1830, Penguin Books, 1953, p. 241

(4) James Stevens Curl, Georgian Anchitecture, David \& (harles, 1993, p. 61

(5) Summerson, op. cit., pp. 239-40

(6) Curl, op. cit., p.56 Curl \&., Breman, P (ed) The Architecture of the Early Eighteenth Century, (London : Weinreb, 1965) Item 46 Catalogue 11 を紹介している.

(7) Terence Davis, The Gothick Taste David \& Charles, 1974, p. 45

(8)参考文献を挙げる.Ph. デュ・ピュイ・ド・クランシャン 『スノビス I』 白水社, 横山訳, 1972

(9)G・M・トレヴェリアン『イギリス社会史 2 』みすずす書房, 松浦・今 井妬, 1983, 259 賁

(10)H・J・ラスキ『イギリス政治思想【一一ロロックからべンサムまで』 岩波書店, 堀・飯坂訳, 1969, 72 頁・・・バークレイ司教は大英帝国の衰 退防止に関寸る試諭」（1721）を出版し，英国人の投機狂的性廦が; 高貴な 道徳的性格に及ぼす影響を心配する。この性廦は南海泡末事件を辧した。

(11) 川北稔『工業化の歴史的前提一一帝国とジェントルマン-D-」岩波 書后，1985，271 頁 (12)Bernard Denvir, The Eighiteenth Century Art, design and society, 1689-1789, Lomgatan, 1988; p. 16

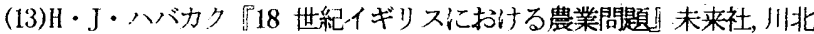
訳, 1967, 15-7 頁

(14)村剛健次・鈴木利章・川北稳『ジェントルマン・その周辺とイギリス 近代 ミネルヴァ書房，1987，121 真および八、゙カク, 前掲書, 1頁

(15)アーノルド・八ウザー『芸術と文化の社会史 $2 』$ 平凡社, 1968, 611 頁

(16) surveyable という語证，一望できる，概観できる，測量できる，も 渡せる，人の目に触记る，目立う等の意味がある. 18 世紀の英国人たちの 間には，阶所有者の人格と社会的な身分を最も明確力強力に象徴すると いう意味での人の目に触える富を富の基本的特性と見な寸考えがあり、兒 渡し可能 (surveyable) な富|こそが富裕の本質と考えられた。 それは,力 ントリー・八ウスや庭園建築物等, 永続性が高く社会的な意味が物的 : 空間 的に明示され易に分野に集中する傾句の強い，人の目に触える資産を言う。

(17) Jonathan Richardson, Essay on the Hhole Art of Criticism as it relates to Painting and a Discourse on the, Certainity, Pleasure, and Advantage of the Science of a Connoisser, 1715 (但し Denvir, op. cit. , p. 10

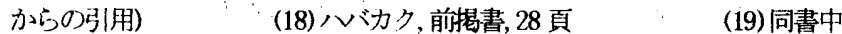

(20) 角山栄・川北 稔『路地裏の大英帝国 イギリス都市生活史』平凡社, 1986,20 頁

(21) Alexander Pope, Epistles to Several Persons (Moral Essay) Epistle $N$ (To Burlington) , Argument of the lise of Riches, Methuen,. Edited, by, F. F. Bateson, 1951, pp. 130-51 および, Epistle III (To Bathurst) Argument of the Use of Riches, pp. 79-121

(22)Custiglione, II Cortegiano，(但し Denvir, op. cit., p.10 からの引用)

(23) Richardson, op. cit.. (但L Denvir.op.cit.p.10からの引用)

(24)John Steegman, The Rule of Taste From George I to George $N$, Macmillan, 1936; p.18 $\quad$ (25) ibid. $\quad$ (26)川北前揭書, 279 頁

$(27) \mathrm{R} \cdot \mathrm{H} \cdot$ トーニ一腙教之資本主義の與隆 下』岩波書店,山口・越智 訳, 昭和 39 年 169 頁

(28)Miles Hadfield, the English Landscape Garden, Shire Publications, 1988. p. 29-32 および Christopher Hussey, English Gardens and Landscape 1700-1750 Country Life, 1967, p.97 (以下 "Gardens" ᄂ以 5)

(29)George Clarke, "Grecian Taste and Gothic Virtue: Lord Cobham's gardening programme and its iconography", Appolla, Vol. XCVII, No.
136, pp. 566-71; (June 1973)

(30) 向かって左側には，詩人，哲人，芸術家等 -8 人の沈思する人， 右側には 8 人の唀動家 -..王政冶家;軍の指導者たちが並ぶ偉人たちは左か ら右八 Pope, Gresham, Inigo Jones Milton. Shakespeare, Incke, Newton, Bacon, Alfred, Edward Prince of Wales Queen Elizabeth, William III, Raleigh, Drake, Hampden, Barnard

(31)ギッブスは 1732年以前にストウ園にこの种殿を建てている. .G・ウ ェストはその年に書いた詩の中にその神殿について だッブス上，汝の神殿 の周りに，皇太子，愛国者, 詩人，哲人から成る神聖な、団が立っている. と歌っている. 彼は、エリザバス女王 ベーコシ, シェクスピア，ハンプデ ン,.,ウィリアム3世, ロック：ニュートン，およびミルトンの名を挙げてい

る. George Clarke は，その神殿を Gibbs Building と呼んでいる.

(32) Clarke, op. cit., 569

(33) ibid. (34)Hussey, "Gardens" p. 102 (35) ibid

(36)John Dixon Hunt. Gandens and Picturesque. MIT Press, 1992 , pp. $79-80$

(38) Hunt, op. cit., pp. 59-60

(37) Clarke, op: cit., pp. 568--569

(40)Rudolf Wittkower, Palladio and English Palladianism. Thames and Hudson, 1974, p.132

(41)ニコラウス・ペウスナー英国美術の英国性、岩崎美術社，友部・蛭 川訳，1981 年，39 頁，(以下"英国美術という)

(42) ニコラウス・ペウススー『新版ヨーロッパ建筑序説』彰国社

小林。山口，竹本訳，1989，296 賁

(43)ベヴスナー，"英国美術”，38-41 頁， T. W. West, English Aichitecture, Shire Publications, 1988, p:25 および John Harries. Churches, Shire Publications. 1976, p.20

(44)West, op. cit. p. 27

(45) Hussey, op. cit., p. 47

(46)Summerson, op. cit., pp. $239-40$

(47)Bernard Denvir, The Late Victorian Art, design and society, 18521910, Longman, 1986, p. 15

(48)ジョン・ロック・貨幣・利子論』東大出版，田中・竹本訳.1982 年.90 91 頁 (49)同書中

(51)Christopher Hussey, English Country House, Early Georgian 1715 -1750. Antique Collector's' Club , 1984,p. 24 (以下 "House" という)

(52)Anthony Ashley Cooper, third Earl of Shaftesbury, Characteristics of Men, Manners, Opinion, Times, Olms Verlag 1711, Vol. I, Part3, Sect.1 p.393

(53) Hussey, "House" ,p. 24

(54)Horaoe Walpole, On Modern Gardening, in the Works of Horace Walpole. Earl of Orford, printed for G. G. and J Robinson MDCCXCVIII Vol. II, p.593

(55) David Watkin. The English Vision, John Murry, 1982, p. 25

(56)Rowan, op. cit., p. 26 (57)McCarthy, op. cit., p. 34

(58)アンドレ・モーロア英国史白水社，水野・浅野訳,昭和，15 年,219 頁

(59)J. H. P lumb. England in the Eighteenth Century, Penguin Books, 1981, p. 72

\section{図版}

(図-1) および (図-4) は, David Watkin, The English Vision, John Murry, 1982, から, (図-2) は, George Clarke, Grecian Taste and Gothic Virtue: Lord Cobham's gardening programme and its iconography. Appolla Vol. XCVII, No. 136, (June1973) 加, (図-3) は, Terence Davis, The Gothick Taste, David \& Charles,1974 加, (図-5) 代, Alistair Rowan, Gothick Restoration at Raby Castle, Architectural History, Vol. 15, 1972 から，(図-6) 位 Michael McCarthy, The Origins of Gothic Revival，Yale University Press, 1987 からう引引用である. 